Abstracta Iranica Abstracta Iranica

Revue bibliographique pour le domaine irano-aryen

Volume 40-41 | 2019

Comptes rendus des publications de 2017-2018

\title{
Nikolaus L. Overtoom. “The Parthians' Unique \\ Mode of Warfare: a Tradition of Parthian \\ Militarism and the Battle of Carrhae"
}

\section{Leonardo Gregoratti}

\section{(2) OpenEdition}

Journals

Electronic version

URL: http://journals.openedition.org/abstractairanica/49685

DOI: $10.4000 / a b s t r a c t a i r a n i c a .49685$

ISBN: 1961-960X

ISSN: 1961-960X

Publisher:

CNRS (UMR 7528 Mondes iraniens et indiens), Éditions de l'IFRI

\section{Electronic reference}

Leonardo Gregoratti, "Nikolaus L. Overtoom. "The Parthians' Unique Mode of Warfare: a Tradition of

Parthian Militarism and the Battle of Carrhae"', Abstracta Iranica [Online], Volume 40-41 | 2019, document 33, Online since 30 October 2019, connection on 16 April 2021. URL: http://

journals.openedition.org/abstractairanica/49685 ; DOI: https://doi.org/10.4000/abstractairanica. 49685

This text was automatically generated on 16 April 2021.

Tous droits réservés 


\title{
Nikolaus L. Overtoom. “The Parthians' Unique Mode of Warfare: a Tradition of Parthian Militarism and the Battle of Carrhae"
}

\author{
Leonardo Gregoratti
}

\section{REFERENCES}

Nikolaus L. Overtoom. “The Parthians' Unique Mode of Warfare: a Tradition of Parthian Militarism and the Battle of Carrhae" in Marek Jan Olbrycht (ed.). Collectanea Iranica et Asiatica. Iran and Western Asia in Antiquity. New Perspectives (Anabasis 8), 2017, p. 95-112

1 The young and productive scholar here provides for the first time a systematic analysis of the Parthian warfare. Most of the previous studies, due to both the lack of detailed and specific descriptions of the Parthian way of fighting and major battles fought by the Arsacids, focused on the most famous and most reported military episode in Parthian history: the Battle of Carrhae. It is author's opinion that the relevant attention given almost exclusively to this military action contributed to shaping the impression that most of the tactics and stratagems adopted by Surena on that occasion constituted a unicum in Parthian fighting history, thus it should not be considered a reliable example of typical Parthian warfare. The author challenges this opinion taking into consideration the tactics adopted by the Parthian in the 2nd and 1st centuries $\mathrm{BC}$, in particular against the Seleucids and Antony. He individuates three main recurring elements in Parthian tactics. The Massed Assault is a blunt attack of heavy armoured cavalry to test enemy's strength, the Hit and Run, a harassment tactic aimed at disorganizing and breaking the enemy lines, through fast manoeuvres and the intense use of the "Parthian Shot". Finally, the Feigned Retreat induces the enemy to attack, seeking close combat, before being surrounded and destroyed. All these tactics appeared well before and well after Carrhae as the author shows. If this idea works 
perfectly at the tactical level the hypothesis that these methods were mirrored by similar ones at the strategical one is, in my opinion, less convincing, but worth to be taken into consideration.

\section{AUTHORS}

\section{LEONARDO GREGORATTI}

Durham University 